\title{
Biology of Palms and Implications for Management in the Landscape
}

\author{
Donald R. Hodel ${ }^{1}$
}

AdDitional INDEX wORDs. anatomy, Arecaceae, distribution, ecology, fruit, habit, inflorescence, leaf, morphology, natural history, roots, stem

SUMMARY. Comprising a natural and distinctive group, palms (Arecaceae) differ from other woody plants in their structure and growth features that require or offer unique and sometimes advantageous landscape management opportunities.

Although palms are a mostly tropical group that lacks dormancy and cold tolerance, there are numerous species possessing sufficient cool or cold hardiness to be suitable for landscaping in subtropical and even some temperate areas. The habit of palms is largely dependent on the number of stems and the length to which they elongate. There are solitary or multistemmed palms and tree or shrub palms. Regardless of habit, there is typically only one growing point or apical meristem per palm stem. Thus, multistemmed palms may be especially versatile landscape subjects because in many instances, one is able to control height and density by judicious removal of stems. The uniquely constructed palm stem, with growth restricted to its extremities (leaves and inflorescences distally, roots proximally, and wholly the product of primary growth), is composed largely of numerous, dispersed, hard, fibroussheathed, vascular bundles embedded in a matrix of water- and carbohydratestoring parenchyma cells. Often likened to a steel-reinforced concrete column and offering tremendous strength and resiliency, palm stems lack a peripheral vascular cambium and, thus, capability for secondary growth, meaning they do not thicken much once they elongate vertically and there is no ability to repair damaged tissue. Thus, care should be taken when performing horticultural tasks to avoid making wounds (which are permanent, unsightly, and potential entry sites for pests and diseases) and damaging the sole apical meristem. A palm's total photosynthetic and reproductive efforts are concentrated into relatively few but large organs (leaves and inflorescences respectively), offering a unique opportunity to capture an entire year's worth of potential leaf, flower, and fruit litter before it falls into the landscape. The palm root system is adventitious and composed of numerous, smallto medium-sized, nonwoody roots. All primary roots are of a more or less constant diameter and arise independently from an area at or near the base of the stem called the root initiation zone. Because of these root system characteristics and the ability of their trunks to store water and carbohydrates, palms are relatively easy to transplant - even large specimens with small root balls - resulting in instant, mature landscapes.

$\mathrm{N}$ o other plant material captures that so-sought exotic and tropical motif as do palms (Fig. 1). A natural and unique group, palms comprise the most distinctive plant materials in our landscape but differ from other woody landscape plants in their anatomy, morphology, and growth features. Cultural practices and techniques for managing landscape palms recognize and accommodate these differences. Presented here is a brief overview of the critical biological features of palms, focusing on their natural history, stems (trunks), roots, leaves, and inflorescences, and how they impact management in the landscape.

University of California, Cooperative Extension, 4800 East Cesar Chavez Avenue, Los Angeles, CA 90022

${ }^{1}$ Corresponding author. E-mail: drhodel@ucdavis. edu.

\section{Natural history}

Although, until recently, flowering plants (angiosperms) were divided into two major groups, they are now divided into three major lineages: basal or primitive angiosperms [magnolia (Magnolia spp.), tulip tree (Liriodendron tulipifera), etc.], monocotyledons (monocots), and dicotyledons (dicots or eudicots) (Angiosperm Phylogeny Group, 2003). Palms are woody monocots, although they do not form wood in the same manner or have the same type of wood as primitive angiosperms, dicots, or coniferous trees. Like other monocots, palms can be distinguished from primitive angiosperms, dicots, and conifers by having one cotyledon (seed leaf) rather than two or more, flower parts (sepals, petals, carpels, etc.) in threes or multiples of threes rather than in twos, fours, or fives, parallel rather than net leaf venation, and vascular bundles (phloem and xylem) dispersed throughout the stem rather than in two concentric rings with a cylindrical primary cambium between them.

Palms can be distinguished from other palm-like monocots, such as beaucarnea and nolina (Nolina spp.), cordyline (Cordyline spp.), dracaena (Dracaena spp.), pandan (Pandanus spp.), and yucca ( (ucca spp.), by their leaf blade usually possessing a prominent midrib (costa or rachis) from which the pinnae (leaflets) or segments arise and unfold and in the inflorescence (flower stalk) always initially enclosed within a two-edged bract (modified leaf) (Tomlinson, 1990). These other palm-like monocots typically possess a cambium for secondary growth, a feature lacking in palms, and aerially branched stems, a feature rare in palms (Tomlinson, 1990).

The palm family comprises 183 genera in about 2400 species, most of which occur in wet, tropical regions (Dransfield et al., 2008). Thus, being a mostly tropical group of plants, palms lack any dormancy mechanism enabling them to tolerate cold without sustaining life-threatening damage (Dransfield et al., 2008; Tomlinson, 1990). Indeed, the lack of heat and, at times, the occurrence of absolute cold, especially during the late fall to late spring months, and to some extent, low relative humidity, are primarily responsible for limiting the number of species that can be grown successfully in most areas of the United States (Hodel, 2008a).

However, some species originate in harsher climates, such as subtropical or even temperate regions, including deserts. Nearly all species suitable for landscaping in California, the southwestern United States, the

\begin{tabular}{llll}
\hline $\begin{array}{l}\text { Units } \\
\text { To convert U.S. to SI, } \\
\text { multiply by }\end{array}$ & U.S. unit & SI unit & $\begin{array}{l}\text { To convert SI to U.S., } \\
\text { multiply by }\end{array}$ \\
\hline 0.3048 & $\mathrm{ft}$ & $\mathrm{m}$ & 3.2808 \\
2.54 & inch $(\mathrm{es})$ & $\mathrm{cm}$ & 0.3937
\end{tabular}




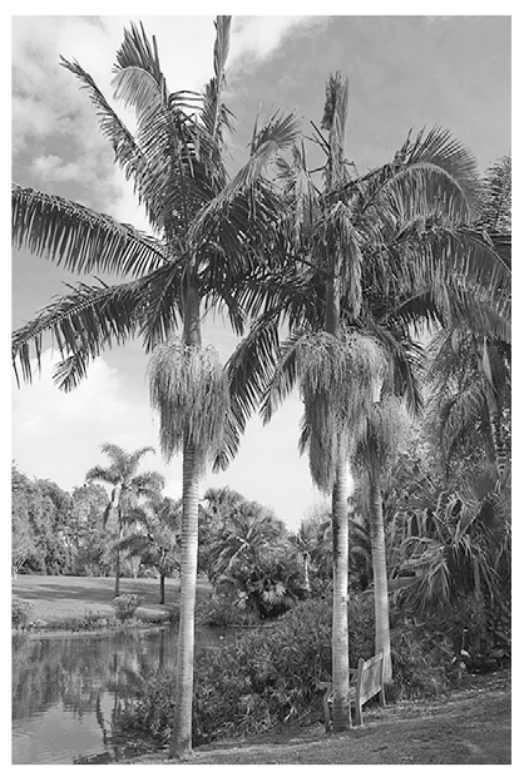

Fig. 1. Elegantly capturing that sosought exotic and tropical motif, palms can be likened architecturally to an elongated axis (stem or trunk) with growth mainly restricted to its terminal extremities, leaves, and inflorescences at the top and roots at the bottom (king palm).

U.S. Gulf of Mexico coast, and northern Florida originate in these harsher climates and are able to tolerate more absolute cold or prolonged cool periods and lower relative humidity (Hodel, 2008a). Surprisingly, some palms can be grown as far north as coastal areas of Pacific northwestern North America (including Vancouver, Canada), southern Oklahoma, and southern Virginia. They are also grown in England, Scotland, and Switzerland, locales noted for their lengthy cool and cold periods.

Like most tropical or nearly tropical areas, southern Florida and especially Hawaii enjoy a year-round, warm, humid, climate with few, if any, limitations on the species of palm suitable for landscaping. Not surprisingly, considering their tropical origins, palms grow most actively during the warmer months (Broschat, 1998; Hodel et al., 2005).

Many species of palms, especially those from less tropical areas, are armed with various types of spines. All parts of a palm may be armed, including the leaves, stem, inflorescences, fruit, and even roots (Tomlinson, 1990). Because this armature is potentially hazardous to passersby and workers, care must be taken when placing armed palms in the landscape. In some cases, it is prudent to remove the offending armature if it poses a threat.

\section{The stem or trunk}

Architecturally, palms are a typically elongated axis (stem or trunk) or series of axes with growth mainly restricted to its (their) extremities: leaves and inflorescences distally and roots proximally (Fig. 1) (Dransfield et al., 2008; Tomlinson, 1990). It is this rather unique architecture that gives palms their easily recognizable and quintessential habit. Furthermore, this growth is remarkable in that it is entirely primary in nature (Dransfield et al., 2008; Tomlinson, 1990, 2006).

Other than the leaves, stems or trunks are the most conspicuous and characteristic feature of palms, and they provide transport and storage of water, minerals, and carbohydrates and mechanical support for the leaf crown (Tomlinson, 1990). The habit of palms is largely dependent on the number of stems and the length to which they elongate or increase in height (Dransfield et al., 2008; Hodel, 2008a; Tomlinson, 1990). There are solitary or multistemmed palms and tree or shrub palms of various mature heights (Dransfield, 1978; Dransfield et al., 2008). Multistemmed palms attain their habit through basal branching of the main stem and can make especially versatile landscape subjects. In California and the southwestern United States, one is able to control the height and density of multistemmed palm clumps through judicious removal of stems, a management practice that would be impossible to employ and that would result in the death of single-stemmed species. (Removal of stems is not recommended in warm, humid areas like Florida where ganoderma butt rot is present because remnant stubs of removed stems are the primary means of entry of this lethal disease.) In a few species, such as dwarf palmetto (Sabal minor) and radicalis bamboo palm (Chamaedorea radicalis), the stem remains short and compact throughout its life, never much elongating and forming a conspicuous, aboveground structure.

Two types of flowering events or strategies, hapaxanthy and pleonanthy, occur in the palm family and can

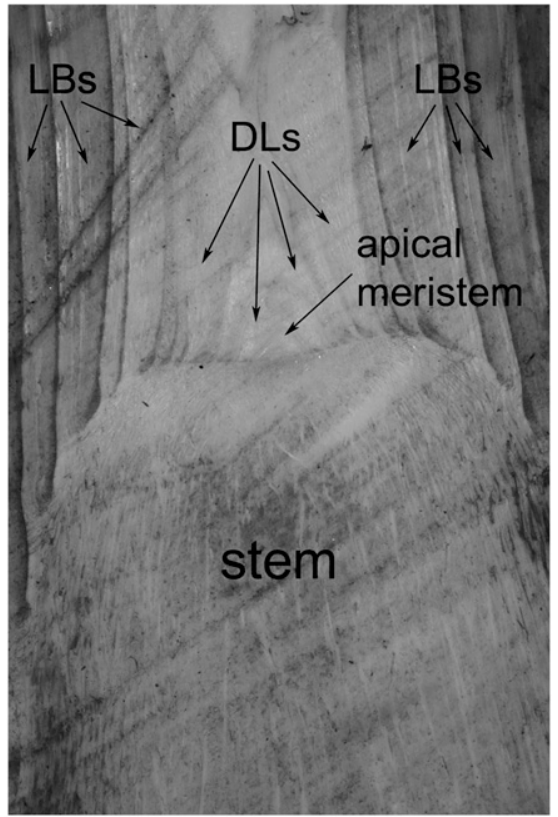

Fig. 2. Palms typically have only one growing point or apical meristem per stem, and it is embedded and protected within a series of older, overlapping leaf bases (LBs) and developing leaves (DLs) (king palm).

influence palm architecture and habit (Dransfield et al., 2008; Tomlinson, 1990). They are discussed below under inflorescences.

Regardless of the number of stems or their length, there is typically only one growing point or apical meristem per stem, and it is embedded within a series of older, overlapping leaf bases, which offers some protection against cold, disease, pests, trauma, and fire (Fig. 2) (Dransfield et al., 2008; Tomlinson, 2006). Aerial branching of palm stems is rare, and occurs naturally and conspicuously in only a few species, such as doum or gingerbread palm (Hyphaene spp.), which are infrequently cultivated, and date palm (Phoenix dactylifera) (Dransfield et al., 2008). Aerial branching sometimes occurs in other species, where it is an abnormal phenomenon thought to be the result of wounding or injury to the apical meristem or nutritional disorders (Broschat, 2007; Hodel, 2008a; Marika and Moore, 2007).

Unlike primitive angiosperms, dicots, and coniferous woody plants, palm stems lack a peripheral primary cambium and capability for secondary growth that continually increase stem diameter and strength by producing 
phloem and bark on the outside of the cambium and xylem or wood on the inside. In contrast, the vascular system in palms is repetitive and redundant, composed of numerous, individual bundles containing phloem and xylem and dispersed throughout the stem (Dransfield et al., 2008; Tomlinson, 1990). Palm stems do become stronger and more rigid over time, however, the result of stem cells that thicken and strengthen with age (Rich, 1987a, 1987b; Tomlinson, 2006).

After attaining their maximum diameter and elongating vertically through primary growth, palm stems thicken little if at all because there is no peripheral cambium for secondary growth (Dransfield et al., 2008; Tomlinson, 1990). This lack of secondary growth also means that there is no ability to repair damaged tissue. Thus, wounds on palm stems, while permanent as well as unsightly, are potential entry sites for pests and diseases (Tomlinson, 1990; Hodel, 2008a). Exercise care when performing horticultural tasks, like transplanting and leaf and inflorescence removal, or simply working around palms, to avoid wounding or otherwise damaging their stems (Hodel, 2008b). Despite this apparent disadvantage and the lack of documented compartmentalization of decay (CODIT) processes common in dicotyledonous and coniferous trees, palm stems are remarkably resistant and resilient to decay, a phenomenon not well understood but thought to be related to the exceptionally hard fibrous sheaths enclosing the vascular bundles (Hodel, 2008a).

In cross section, the palm stem has two distinct regions, the cortex and central cylinder (Fig. 3) (Tomlinson, 1990). The cortex, a very narrow band on the outside of the stem, has a thin outer covering or skin composed primarily of thick-walled, sclerified (hardened) cells, which is sometimes referred to as pseudobark, although it has no relation to bark of dicotyledonous and coniferous trees. Relatively unspecialized parenchyma cells, which may become larger, more numerous, and lignified (woody) with age, compose most of the remainder of the cortex.

The central cylinder lies within the cortex and comprises a majority of the area of the palm stem. It is composed primarily of numerous, dispersed, light- or dark-colored, hardened vascular bundles containing phloem (carbohydrate transport) and xylem (water and mineral transport) embedded in a mostly homogeneous, light-colored, hardened ground tissue made up largely of unspecialized parenchyma (Dransfield et al., 2008; Tomlinson, 1990). The parenchyma cells, which store water and carbohydrates as starch, tend to become woody with age, especially those toward the outer part of the central cylinder, while those toward the center of the central cylinder are mostly spongy and unlignified (Tomlinson, 2006). This storage capacity of palm stems facilitates transplanting by supplying a ready source of water and carbohydrates until roots regrow and leaves are again functioning fully. Thoroughly irrigating palms before transplanting uses this storage capacity to full advantage.

A strong, hard, fibrous sheath partially or entirely encloses each vascular bundle and is the primary mechanical support for the stem (Dransfield et al., 2008; Tomlinson, $1990,2006)$. In most palms, the vascular bundles are concentrated toward the periphery of the central cylinder for maximum strength and support. Thus, the palm stem can be likened structurally to a steel-reinforced, concrete column (Tomlinson, 1990). The vertically oriented vascular bundles are the steel rebar and the ground tissue is the concrete matrix. The result is an exceptionally strong and fairly flexible stem that rarely breaks.

\section{Leaves}

Leaves are probably the most conspicuous and characteristic feature of palms (Dransfield et al., 2008). Produced sequentially at the apex of the stem, they are the result of primary growth from the same apical meristem responsible for stem initiation, development, and thickening (Tomlinson, 1990). Because they are produced sequentially, the newest leaves are always in the center or upper part of the crown and, as they age, are displaced or "pushed" to the lower part of the crown.

The palm leaf is composed of three parts: the blade, the petiole, and the base (Dransfield et al., 2008; Tomlinson, 1990). The blade is the expanded, usually conspicuously enlarged, multiribbed or -folded, typically divided, and often flattened

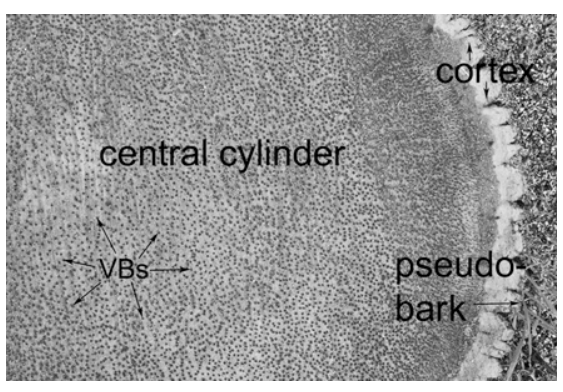

Fig. 3. Anatomically in cross section, the palm stem has two distinct regions, the cortex and central cylinder, although there is no clearly identifiable layer between them. The vascular bundles (VBs) appear as dark dots in the central cylinder (mexican fan palm).

surface with the primary function of collecting sunlight for photosynthesis and exchanging gases for respiration and transpiration. The petiole is typically a slender, often elongated organ that supports and attaches the blade to the base or sheath. The base clasps and holds the entire leaf to the stem.

There are two major types of palm leaves defined by the degree to which the petiole extends into the blade as a rachis (Dransfield et al., 2008; Tomlinson, 1990). In palmateleaved or fan palms, the rachis is short (costapalmate) or nearly nonexistent, the ribs (folds) or segments radiating from a more or less central point. In pinnate-leaved or feather palms, the rachis is extended and elongated, the ribs (folds) or pinnae (leaflets) attached along its length.

Leaves are of primary importance to landscape managers because of their litter-producing potential. Fortunately, in palms, total green tissue biomass in the leaf crown follows the "concept of aggregation" and is gathered into relatively few but large leaves, offering a unique opportunity for litter management (Fig. 1) (Hodel, 2008a, 2008b). With a few timely pruning cuts, an entire year's worth of potential leaf litter can be captured and removed before it falls to the ground, an impossible and unthinkable task for a dicotyledonous or coniferous tree.

In many species, the base does not abscise neatly and cleanly when the leaf senesces, and old, dead leaves can persist on the palm long after they have died. "Skirts" or "petticoats" of old, dead, persistent leaves, clothing a stem 
for considerable distance, are a common and not necessarily unattractive feature of some palms, such as mexican fan palm (Washingtonia robusta) and california fan palm (Washingtonia filifera). However, if the "skirt" becomes uneven, ragged, or unsightly, or poses a hazard from falling debris, it should be removed (Hodel, 2008b).

Even if the blade and petiole are removed, the base can remain securely attached to the stem for many years, sometimes for the life of the palm, and attempting to remove it prematurely can wound the stem, leaving permanent and unsightly scars. The process of skinning palm stems to remove persistent leaf bases can create huge, gaping wounds, and is generally discouraged (Hodel, $2008 b$ ). In species that retain their dead leaves, petioles frequently become woody and rigid as in pindo palm (Butia capitata) and various date palms (Phoenix spp.), and if not cut closely and neatly to the base, can pose a hazard to pedestrians and workers (Hodel, 2008b).

In some species, the leaf bases are elongate and tubular and form a conspicuous, sometimes swollen structure called a crownshaft (Dransfield et al., 2008). In palms with a crownshaft, leaves typically abscise neatly and completely as a single, intact unit (base, petiole, and blade together), often thrust off by the expanding inflorescence just inside the base (Fig. 1). Such species are commonly referred to as self-cleaning palms.

\section{Inflorescences}

Although small and individually mostly insignificant, palm flowers (and eventually fruit) are aggregated into usually large clusters of numerous flowers called inflorescences (Dransfield et al., 2008; Tomlinson, 1990; Tomlinson and Moore, 1968). Depending on their size and placement, palm inflorescences can be conspicuous and even showy. The basic inflorescence consists of a typically elongated central axis with up to five progressively smaller or more slender orders of branches (Dransfield et al., 2008). The ultimate branches hold the flowers and fruit.

Inflorescences, because of the numerous flowers and fruit that they produce, are a potential and significant source of litter (Hodel, 2008c). Fruit are of special concern because of the potential for messy, abundant, hardscape-discoloring or -staining litter, the hazard posed to pedestrians, and the fruit-eating animals they might attract (Hodel, 2008c).

In some species, such as bamboo palm (Chamaedorea spp.) and especially sugar palm (Arenga spp.), fishtail palm (Caryota spp.), carpenteria palm (Carpenteria acuminata), and macarthur palm (Ptychosperma macarthurii), fruit contain needle-like calcium oxalate monohydrate crystals (Dransfield et al., 2008) that can be highly irritating if ingested or if their juice or sap contacts unprotected skin (see Broschat and Latham, 1994 for a list of 60 species of palms with such crystal-containing fruit). Care should be taken to remove and dispose of fruit of these species safely if they are readily accessible to unwary passersby and especially children who may be attracted to the brightly colored, ripe fruit (Hodel, 2008c).

Fortunately, like leaves, it is relatively easy to capture and collect a year's or season's worth of potential litter before it falls with a few timely pruning cuts because total reproductive biomass is aggregated into relatively few inflorescences (Fig. 4) (Hodel, 2008a, 2008c). Even if litter is not a problem, consider removing old, spent inflorescences because they can persist on the palm, giving it a messy and unkempt appearance and detracting from its esthetic value. Inflorescences may be removed as closely and neatly as possible, without damaging the stem, after they have fully elongated but before fruit maturation and drop. Keep in mind that in some species, inflorescences can elongate considerably after flowering and pollination and before fruit maturation.

Inflorescences are typically produced in the axil of each leaf once the palm attains maturity (Dransfield et al., 2008). While inflorescence production can be continuous, especially in species from wet tropical areas, it is typically periodic in subtropical and temperate areas with distinct seasons defined by temperature, rainfall, and/or daylength that trigger or otherwise influence production. Understanding and appreciating the seasonal nature of inflorescence production are important in the timing of their removal to control litter.

Two types of flowering events, hapaxanthy and pleonanthy, can occur

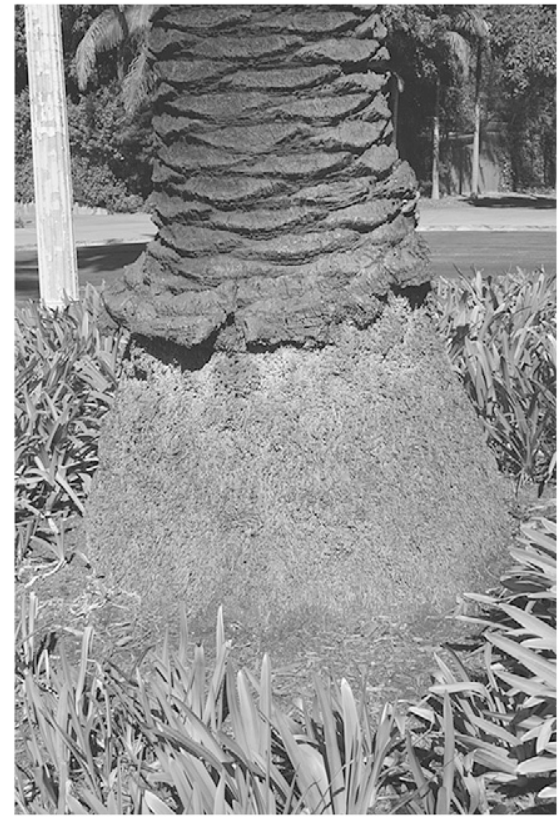

Fig. 4. The palm root system is composed of numerous, adventitious, slender, often fibrous primary roots that initiate independently and periodically from the root initiation zone at the base of the trunk (canary island date palm).

among palms, and each is defined by whether the production of inflorescences does or does not limit the growth of the stem (Dransfield et al., 2008; Tomlinson, 1990). In pleonanthy, which is the most common condition in palms, flowering is indeterminate to the stem because the production of inflorescences and leaves continues indefinitely until the palm senesces and dies.

In hapaxanthy, which is less common in palms, flowering is determinate because the production of inflorescences reorganizes the stem into a flowering axis and signals the eventual and fairly imminent death of that stem as a vegetative organ.

With single-stemmed species, hapaxanthy results in the death of that palm, and the species is truly monocarpic (once fruiting). In most multistemmed species, however, hapaxanthy results in the death of that stem only, and the palm continues to live by virtue of the remaining stems. Hapaxanthy, especially in singlestemmed species, can result in significant and conspicuous morphological changes. Inflorescence production typically is initiated at the top of the stem, progresses distally or proximally 
(Dransfield et al., 2008), and is often preceded by a marked reduction in leaf size (Tomlinson, 1990).

Common hapaxanthic palms include dwarf sugar palm (Arenga engleri), clustered fishtail palm (Caryota mitis), and giant fishtail palm (Caryota maxima), the last being truly monocarpic because it is singlestemmed. Stems that have died from hapaxanthy are best removed because they are unsightly and will eventually pose a hazard from falling (Hodel, 2008a). Because some species, such as the giant fishtail palm, have large, heavy, intractable stems that will be cumbersome and difficult to remove, even with heavy machinery, care must be taken in their selection and placement in the landscape.

\section{Roots}

The palm root system is adventitious in nature, and composed of numerous, relatively small, nonwoody roots, of which all primary roots are of a more or less constant diameter and arise independently and periodically from an area at or near the base of the stem called the root initiation zone (RIZ) (Fig. 4) (Dransfield et al., 2008; Tomlinson, 1990). It is this adventitious, constantly or periodically renewing root system that largely makes it possible to transplant large specimens with a relatively small root ball. Full or nearly full development of the RIZ enhance transplant success in some but not all species of palms (Broschat and Donselman, 1990a; Hodel and Pittenger, 2003; Hodel et al., 2003).

The RIZ is typically at or near ground level but can extend for a considerable distance above the ground. Especially in unusually humid conditions and/or if a sprinkler is regularly applying water to that area of the stem, roots can form several meters above the ground. The mass of exposed roots at the base of the stem, if conspicuously enlarged as in canary island date palm (Phoenix canariensis) or mexican fan palm, is referred to as a "root boss" (Dransfield and Uhl, 1987).

Not all roots emerging from the RIZ grow into the soil. An abnormal and potentially lethal development, called "inverted root cone" (Hodel, 2008 c) sometimes occurs and is caused by too shallow planting, errant monofilament weed trimmers, and, at least in California, arid conditions that effectively "air-prune" emerging roots, preventing them from reaching the soil. Many roots stop growing once they have emerged and appear as short root initials or nubs. In severe cases, an insufficient number of roots grows into the ground and the stem actually is much wider than the cylinder or cone of roots supporting it. Inverted root cone could pose a hazard because the roots may be insufficient to anchor and support the stem adequately and it may topple over, especially during strong winds (Broschat and Meerow, 2000; Hodel, 2008c).

A natural accumulation of leaf litter around the base of the stem facilitates root growth into the ground in the wild. Thus, to treat inverted root cone, apply and maintain mulch or mound good quality top soil around the base of the palm sufficiently high to cover exposed root initials. Keeping the mulch or mounded soil moist will encourage roots to grow down through the organic matter or soil into the ground (Hodel, 2008c). However, if mulch is used, it must be regularly replenished because it will shrink and settle with oxidation, pulling away from the trunk and exposing any roots that may have begun to grow into it but have not yet reached the soil. An alternative it to reset the palm to a lower grade, a potentially more difficult, expensive, and time-consuming operation. Keep turfgrass and other plants and string trimmers away from the RIZ, and for new installations, plant palms at grade.

Like the stem, palm roots lack a mechanism for secondary growth and thickening, and, thus, once formed, do not increase in diameter. However, cut roots frequently regenerate, a phenomenon not well understood in light of the fact there is no known mechanism for secondary growth. Nonetheless, the ability of palm roots to regenerate when cut, along with the generation of new roots from the RIZ, is critical to the ability of transplanted palms to establish successfully (Broschat and Donselman, 1984a, 1984b, 1990a, 1990b; Hodel et al., 2005).

Most palm roots are found in the upper $30 \mathrm{~cm}$ of soil and close to the base of the palm trunk (Hodel et al., 2005 ). Indeed, primary roots typically branch into an extensive network of secondary, tertiary, and quaternary orders of roots that often form a rather dense and compact system referred to as a "root mat" (Tomlinson, 1990) immediately around the base of the trunk and spreading outward for several meters, sometimes for as many as $40 \mathrm{~m}$ (de Granville, 1974; Seubert, 1997).

Most water and nutrient absorption occurs in the fine tertiary and quaternary root orders, which typically are most extensively developed near the soil surface (Tomlinson, 1990). Under optimal growing conditions, such as the presence of even or constant moisture and a humus layer, these absorptive roots achieve their greatest number and density, pointing out the importance of mulches and judicious irrigation in proper palm management (Hodel, 2008c).

That palm roots arise and mostly grow in the upper $30 \mathrm{~cm}$ of soil (Hodel et al., 2005) indicates that they require abundant oxygen for optimal growth (Broschat, 1995). Compacted, poorly drained and aerated, water-logged soils and too deep planting restrict oxygen and result in poor root growth. Such poor growth can lead to disease problems and nutrient deficiencies (Broschat, 1995).

In tropical regions where temperatures, humidity, and moisture are not limiting, palm roots emerge and grow year round, sometimes in distinct flushes (Broschat, 1998). However, in regions with distinct growing seasons defined by temperature and/ or moisture, such as the southwestern United States, roots grow mostly during the warmer months and when rain or irrigation water is present (Hodel et al., 2005). Low root activity during the cool winter months can lead to nutritional deficiencies, especially with iron and nitrogen (Broschat, 1995). Consider a late summer or fall application of a palm special fertilizer to ensure nutrient levels are adequate before the onset of cooler weather.

Mycorrhizae are associated with many, if not all, species of palms (Broschat and Elliott, 2009). Although there is a large body of work on association of mycorrhizae on palms in natural settings, there is little research-based information on their horticultural use and effectiveness. However, as with other woody plants, 
mycorrhizae are probably present in sufficient quantity in most landscape situations, and it would likely be beneficial to add them only in certain and extreme conditions, such as when planting seedlings in a sterilized soilless medium or larger palms in freshly degraded subsoils, both situations where mycorrhizae have had insufficient time to recolonize the growing medium or substrate (Hodel, 2008c).

The nonwoody nature of the palm root system precludes or lessens hardscape damage like that which basal angiosperms and dicotyledonous or coniferous trees with their woody, branched root systems might inflict. However, in some instances, the sheer number of roots and the size of the expanding root mat or root boss are sufficient to damage hardscape, primarily by shifting it up or down or to the side rather than by cracking or breaking it (Hodel, 2008c).

\section{Literature cited}

Angiosperm Phylogeny Group. 2003. An update of the angiosperm phylogeny group classification for the orders and families of flowering plants: ApgII. Bot. J. Linn. Soc. 141:399-436.

Broschat, T.K. 1995. Planting depth affects survival, root growth, and nutrient content of transplanted pygmy date palms. HortScience 30:1031-1032.

Broschat, T.K. 1998. Root and shoot growth patterns in four palm species and their relationships with air and soil temperatures. HortScience 33:995-998.

Broschat, T.K. 2007. Boron deficiency, phenoxy herbicides, stem bending and branching in palms: Is there a connection? Palms 51:161-163.

Broschat, T.K. and A.W. Meerow. 2000. Ornamental palm horticulture. University Press of Florida, Gainesville, FL.
Broschat, T.K. and H. Donselman. 1984a. Regrowth of severed palm roots. J. Arboriculture 10:238-240.

Broschat, T.K. and H. Donselman. 1984b. Root regeneration in transplanted palms. Principes 28:90-91.

Broschat, T.K. and H. Donselman. 1990a. IBA, plant maturity, and regeneration of palm root systems. HortScience 25:232.

Broschat, T.K. and H. Donselman. 1990b. Regeneration of severed roots in Washingtonia robusta and Phoenix reclinata. Principes 34:96-97.

Broschat, T.K. and M.L. Elliott. 2009. Effects of fertilization and microbial inoculants applied at transplanting on growth of mexican fan palm and queen palm. HortTechnology 19:324-330.

Broschat, T.K. and W.G. Latham. 1994. Oxalate content of palm fruit mesocarps. Biochem. Syst. Ecol. 22:89-92.

de Granville, J.J. 1974. Apercu sur la structure des pneumatophores de deux especes de sols hydromorphes en Guyane. Generalisation au system respiratoire racinaire d'autres palmiers. Cahier Office de la Recherche Scientifique et Technique d'Outre-Mer, series Biologie 23:3-22.

Dransfield, J. 1978. The growth forms of rain forest palms, p. 247-268. In: P.B. Tomlinson and M.H. Zimmerman (eds.). Tropical trees as living systems. Cambridge University Press, New York.

Dransfield, J. and N.W. Uhl. 1987. Genera palmarum, A classification of palms based on the work of Harold E. Moore, Jr. L.H. Bailey Hortorium and International Palm Society, Lawrence, KS.

Dransfield, J., N.W. Uhl, C.B. Asmussen, W.J. Baker, M.M. Harley, and C.E. Lewis. 2008. Genera palmarum. The evolution and classification of palms. Kew Publishing, Royal Botanic Gardens, Kew, UK.

Hodel, D.R. 2008a. Palms in the landscape: Palm biology and implications for management. Part 1. Wesern Arborist 34(2):18-30.
Hodel, D.R. 2008b. Palms in the landscape: Palm biology and implications for management. Part 2. Western Arborist 34(3):14-22.

Hodel, D.R. 2008c. Palms in the landscape: Palm biology and implications for management. Part 3. Western Arborist 34(4):1-8.

Hodel, D.R. and D.R. Pittenger. 2003. Studies on the establishment of date palm (Phoenix dactylifera 'Deglet Noor') offshoots. Part I: Observations on root development and leaf growth. Palms 47: 191-200.

Hodel, D.R., D.R. Pittenger, and A.J. Downer. 2005. Palm root growth and implications for transplanting. J. Arboriculture 31:171-181.

Hodel, D.R., D.R. Pittenger, A.J. Downer, and W.E. Richie. 2003. Effect of leaf removal and tie up on juvenile, transplanted canary island date palms (Phoenix canariensis) and queen palms (Syagrus romanzoffiana). Palms 47:177184.

Marika, M. and R. Moore. 2007. Abnormal branching in palms. Palms 51:58-62.

Rich, P.M. 1987a. Developmental anatomy of the stem of Welfia georgii, Iriartea gigantea, and other arborescent palms: Implications for mechanical support. Amer. J. Bot. 74:792-802.

Rich, P.M. 1987b. Mechanical structure of the stem of arborescent palms. Bot. Gaz. 148:42-50.

Seubert, E. 1997. Root anatomy of palms. I. Coryphoideae. Flora 192:81-103.

Tomlinson, P.B. 1990. The structural biology of palms. Oxford University Press, New York.

Tomlinson, P.B. 2006. The uniqueness of palms. Bot. J. Linn. Soc. 151:4-14.

Tomlinson, P.B. and H.E. Moore, Jr. 1968. Inflorescence in Nannorrhops ritchiana (Palmae). J. Arnold Arbor. 49:16-34. 